of carcinoma of the sternal gastroscopy is considered of undoubted value but we do not undenstand why the author states that it cannot be generally adopted. We note with satisfaction the advocacy of graded operations in the surgery of cancer of the colon.

A feature of this book is the excellent diagrams over which it is obvious that much trouble has been expended. Many of the diagrams are in colour which is an excellent aid to the memory. The book is beautifully produced and in that it embodies the results of many years experience both of clinical work and teaching it is to be recommended to all who desire an arresting volume dealing with diseases of the digestive system.

\section{PYE'S SURGICAL HANDICRAFT.}

Edited by Hamilton BaIley. 12th Edition. Pp. 595. Bristol: John Wright \& Sons, Ltd. London: Simpkin Marshall, Ltd. 1940. Price 21s. 0d.

Fifty-six years have elapsed since Walter Pye enriched medical literature by the publication of his book on Surgical Handicraft. The book was a great success and a second edition was published a year later. During subsequent years no less than 12 editions have appeared and this in itself is adequate proof of the value of this work. The present edition is edited by Hamilton Bailey who has elicited the help of a large number of contributors responsible for specific subjects.

The subject matter of the book is essentially practical containing valuable information which House Surgeons are continuously requiring. It may be said that this is a book which should be possessed and studied by every House Surgeon for thereby his efficiency would be markedly improved. The subjects covered are most comprehensive and precise practical details are supplied in each case. Chapters are devoted to the relationship of the House Surgeon to the pathological and radiological departments and with the nursing staff of a hospital and useful information is also given concerning hospital administration.

This book is strongly recommended as one of the best of its kind to all House Surgeons and to medical practitioners, knowing that they will find in it a wealth of knowledge regarding problems which are daily recurring.

\section{FORTHCOMING MEDICAL BOOK.}

OXFORD MEDICAL PUBLICATIONS.

"A Practical Manual of Diseases of the Chest," by Maurice Davidson, M.A., M.D., F.R.C.P. 2nd Edition. Pp. xiv +575 , with one coloured plate and 200 illustrations. Price 2 guineas net.

\title{
Miscellaneous.
}

This Section deals with New Drugs, Preparations, Surgical Instruments, etc. The description of each article is supplied by the Producer. Particulars regarding in sertions, which are free of cost, may be obtained from the Business Manager, Fellowship of Medicine and Post-Graduate Journal, 323, Grand Buildings, W.C.2.

SULPHANILAMIDE POWDER BOOTS - Recent articles in the medical press have described the use of Sulphanilamide Powder as a local Boots Pure Drug Co., Ltd. application in the treatment of wound infections. From 5 to $15 \mathrm{gm}$. of Sulphanilamide are incorporated into the depths of the wound at the time of debridement to prevent the spread of bacteria in and around the wound, the amount of powder used depending on the extent of the trauma. The results so far obtained have been very encouraging.

Sulphanilamide Powder (Boots) is supplied in cartons containing 10 packets of 15 gm., 7s. 6d. Subject to 15 per cent. discount to the medical profession. Literature and a sample of this product may be obtained on application to Medical Information Dept., Boots Pure Drug Co., Ltd., Station Street, Nottingham.
H. K. LEWIS \& Co. Ltd.

MEDIGAL PUBLISHERS AND BOOKSELLERS I36 GOWER ST. LONDON, W.C.I

(Adjoining University College and Hospital)

Telephone: EUSton 4282 (5 lines)

Telegrams: Publicavit, Westcent, London

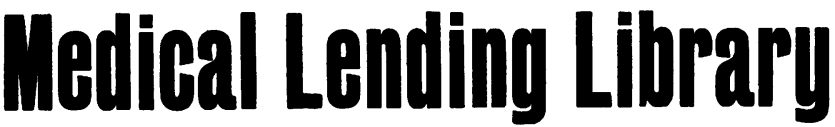

ANNUAL SUBSCRIPTION from ONE GUINEA

FOR THE CONVENIENCE OF POST-GRADUATE STUDENTS SHORT PERIOD SUBSCRIPTIONS ARE ARRANGED-FOR THREE OR SIX MONTHS

DETAILED PROSPECTUS ON APPLICATION

READING ROOM FOR SUBSCRIBERS

NEW BOOKS ADDED IMMEDIATELY ON PUBLICATION 